\title{
Pessimistic Fallibilism and Cognitive Vulnerability
}

Richard Rorty as an Example

Ángeles J. Perona

\section{CpenEdition}

Journals

Electronic version

URL: http://journals.openedition.org/ejpap/1862

DOI: 10.4000/ejpap.1862

ISSN: 2036-4091

Publisher

Associazione Pragma

Electronic reference

Ángeles J. Perona, «Pessimistic Fallibilism and Cognitive Vulnerability », European Journal of Pragmatism and American Philosophy [Online], XII-1 | 2020, Online since 16 June 2020, connection on 26 June 2020. URL : http://journals.openedition.org/ejpap/1862 ; DOI : https://doi.org/10.4000/ejpap 1862

This text was automatically generated on 26 June 2020.

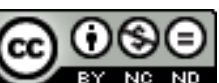

Author retains copyright and grants the European Journal of Pragmatism and American Philosophy right of first publication with the work simultaneously licensed under a Creative Commons AttributionNonCommercial-NoDerivatives 4.0 International License. 


\section{Pessimistic Fallibilism and Cognitive Vulnerability}

Richard Rorty as an Example

Ángeles J. Perona

\section{AUTHOR'S NOTE}

This research has been carried out within the framework of the Cognitive Vulnerability, Verisimilitude and Truth (FFI2017-84826-P) research project and the Rationality, knowledge and action Complutense Research Group (930664). I appreciate all the comments received regarding a previous version of this text by my project partners, especially José $\mathrm{M}^{\mathrm{a}}$ Ariso, Rosa Calcaterra, Isabel Gamero, Óscar González Castán, Marcia Martínez, Javier Vilanova and Astrid Wagner. For the same reason I would like to thank Guido Baggio, Michella Bella and Giovanni Maddalena.

\section{Some Ideas from Rorty's Thinking: Ethnocentrism, Rationality and Solidarity}

1 Let us start by recalling some ideas that stand out in Rorty's thinking.

2 1. Rorty's harsh criticism of the inherited philosophical tradition does not leave a gap of extreme scepticism but a resignification of all cognitive activity (starting with science and ending with philosophy), which can be understood as voices in the conversation of humankind.

3 2. As far as philosophy is concerned, Rorty considers it necessary to abandon the traditional attempt to offer a definitive vocabulary, capable of providing normatively unappealable descriptions of knowledge, truth, good, justice, etc.

4 3. With regard to this, he confers to philosophy the task of inventing vocabularies. This is what he himself does when making his proposal, which, to differentiate himself from 
any realism or relativism, he calls ethnocentrism. Its core is a contingentism that could be summed up in the theory that only descriptions of procedures that a specific society - ours - follows in one area of inquiry or another regarding rationality and its norms (such as truth or justification) can be given (Rorty 1991: 23 et sq.).

5 4. Rorty himself confesses that he prefers to consider his proposal as more of a narrative of maturation than a theory of rationality (Rorty 2000a: 24). The reason for this lies in his idea that any known theory of rationality incurs, in one way or another, in metaphysical realism and a conception of the norms of rationality that fall (manifestly or surreptitiously) into the categories of necessity and, ultimately, of absolute foundation.

6 However, a quick look at the history of philosophy shows reflections on human rationality that are neither necessarist nor fundamentalist. Failure to grasp the difference of moderate scepticism (for example of Hume) or the various fallibilisms that populate twentieth century philosophy (from Popper to Putnam) can only be explained by what Richard Bernstein calls Cartesian Anxiety. It is a philosophical condition consisting of addressing issues in exclusive dualistic terms. Something that, as Bernstein rightly points out, Rorty helped to combat, despite incurring in it, to his regret, in some cases (Bernstein 1983: 60 et sq.; Bernstein 1986: 46-57). Therefore, when Rorty makes statements like the previous one, he actually does so with the idea that contingentism is either professed as he understands it in his ethnocentric proposal or it falls into necessitarianism.

7 5. That same condition explains why Rorty affirms that his pragmatism does not have a relativistic epistemology, because it has none (Rorty 1991: 24). However, reading his work is sufficient to see that he does elaborate and staunchly defends a conception of rationality and an epistemology that contains notions of truth and justification belonging to the coherentist and fallibilist type. In fact, he elaborates his proposal through a continuous debate with other thinkers, many of who present philosophies that also belong to that third option which is fallibilism. However, this path has been trodden by many, so, once on it, it is worth noting, even briefly, the differences between the several types of fallibilism. In this regard, as I will argue below, the fallibilism sustained by Rorty is pessimistic.

6. The previous statement that his pragmatism has no epistemology is followed by the claim that it has an ethical basis, that which appreciates the value of human inquiry in cooperation, which appreciates what each individual offers the community through their inquiries. Hence the primacy of the value of solidarity over that of objectivity. From this perspective governed by solidarity, he understands that inquiring consists of continuous reweaving of a belief network (Rorty 1991: 26). Furthermore, all inquiry is interpretation and all thought is recontextualization of beliefs. ${ }^{1}$

This vision of the inquiry is anti-representationalist (with respect to the realism of the truth), and not sceptical/nihilistic, because he believes in the possibility of a choice between better and worse options. However, we cannot resort to something alien to each ethnos to do this. Rorty believes that this conception of the norms of rationality has the advantage of not claiming "metaphysical activism" (Rorty 1998: 41). In other words, it frees human beings from the task of inventing false gods: a final arbiter who, from the point of view of the Eye of God, establishes the Truth in an absolute and necessary way. 
10 7. The fact is that the primacy of solidarity leads to what he describes as Sartre's consistent atheism. (Rorty 1998: 54, 62). This striking and interesting label refers, among other things, to the idea that human rational activities and their norms are tinged with contingency, as it could be otherwise since there are no unconditioned conditions of any human activity. This is a position for which justification is always limited to an audience, is not necessary, can change and what was true for one audience, will cease to be true for another. In short, rational activities are fallible. That is how Rorty assumes the impossibility of adopting God's eye view or the like until the end.

\section{Fallibilism, Negative Logic and Cognitive Vulnerability}

11 Rorty's theory on the impossibility of adopting a divine point of view is common to all fallibilist models of rationality, which always operate according to what we could call a negative logic. With this expression I mean that, for fallibilist epistemologies, the recurring corroboration of past errors together with the meta-induction of the possibility of future error constitute the centre of the conceptual network that explains the dynamics of rationality (theory and practice). That is why fallibilist philosophies leave no error or doubt outside the scope of rational activities (knowledge and action), as if they were something alien or contrary to them. ${ }^{2}$ On the contrary, both elements are within that scope and play a key role. In this way, fallibilist philosophies show images of what we could call soft rationality. I do not intend to convey any disapproval with this description; its function is descriptive, because I want to highlight the differences of that image of rationality in comparison with the models of hard rationality, those that hold absolute and necessary notions of truth and justification. ${ }^{3}$ The fact is that for fallibilist perspectives, rational activity of any kind is carried out and advances not so much through the positive search for truth or for an absolute foundation free of doubts, but rather through moderate and limited doubt about what is considered verisimilar at the time (or true in a non-absolute sense) and by trying to detect errors. However, this negative logic does not necessarily imply an epistemic pessimism regarding the human capacity to know aspects of reality, that is, to succeed in some way. ${ }^{4}$

12 To explain the possibility of cognitive success, fallibilist philosophies take sides regarding which notion of truth to maintain and that always creates problems, even today. Some classic fallibilist philosophies opt for a combination of instrumentalism and a notion of truth. This is the case with Peirce and the idea of truth as convergence highly criticised by Rorty, that is, as hope that, at the hypothetical end of the research, the community of researchers would come to an agreement. Another variant of that combination is in Popper's epistemological Darwinism, for which the truth is a regulatory ideal that we instinctively pursue. ${ }^{5}$ More recently, the changes that Putnam introduced to his realism - from internal (Putnam 1981) to natural or direct (Putnam 1999: 3-20) - are a good reflection of the huge philosophical difficulty of trying to take charge of all conceptual and evaluative mediations of our cognitive processes without simultaneously ending up in some antirealistic internism or in some metaphysical realism that always seems threatened by the risk of being dogmatic. In the lengthy debate that Rorty and Putnam had throughout their professional lives, ${ }^{6}$ the former 
strongly criticised the realistic proposals of the latter repeatedly accusing him of metaphysical relapses. I will come back to this problem later.?

All the above shows that each fallibilist perspective takes charge of the limits of rational activities and derives consequences on the possibilities of error and cognitive success that may accompany those of error. On the other hand, fallibilism has also shown the importance of the reliability of our rational interactions with the surrounding reality and with others. In short and in general, fallibilisms have opened the way to a more extensive reflection on the scope of what we might call our cognitive vulnerability. ${ }^{8}$

It is understood that I do not see cognitive vulnerability as something that has a negative connotation. That connotation appears in the context of clinical psychology and indicates that the expression refers to psychological disorders, such as anxiety or depression, which are caused by the use of certain schemes or patterns of inadequacy, failure or loss. It assimilates cognitive vulnerability to cognitive distortions that generate negative thoughts about oneself, the world and the future. ${ }^{9}$

Unlike that pathological vision, I see cognitive vulnerability, in fallibilist epistemologies, as a way to bear in mind the limitations of our cognitive abilities and the conditions to exercise them. To which it should be added that all this does not imply in itself either the impossibility of cognitive success, or having a certain confidence in our belief systems. This is the case even though the attempts to clarify this possibility generate enormous difficulties in philosophy (as I have already shown). The latter, by the way, is another manifestation of cognitive vulnerability.

On the other hand, cognitive vulnerability is a manifestation of general human vulnerability, as our belief systems are intertwined with life forms, in the Wittgensteinian sense of the term. Therefore, cognitive vulnerability would in some way reactivate in the epistemological realm the old and prudent sceptical precept of "looking carefully" in order to avoid dogmatic illusions; but it also deactivates the most extreme scepticism as destiny. Along with this, cognitive vulnerability offers us a certain image of ourselves as humans, because what would we be like if we were invulnerable in the cognitive sense and in general? In the cognitive sense, we would be infallible like a divinity (at least intensively); in general, we would be almighty, for example, like the characters that appear in the comics published by Marvel. In short, we would be non-human.

17 Therefore, I understand cognitive vulnerability as a broader category than fallibilism. It includes some type of fallibilism, but also other factors that condition knowledge processes and that have been formulated by different thinkers, although not categorised as manifestations of cognitive vulnerability.

18 For example, the individual psychological elements that work even in the processes of choice between scientific theories. Thomas S. Kuhn noted their huge relevance and wondered why the incidence of these subjective factors in scientific research was considered by its critics an index of human weakness instead of the nature of scientific knowledge. For him they constituted "an index only of the inevitable imperfection of human nature" (Kuhn 1977: 326). We would say that they are an index of human vulnerability in general and, therefore, are also constitutive elements of human beings when they investigate. Furthermore, although Kuhn uses an adjective with a negative connotation ("imperfection"), he does not consider that this draws dramatic 
consequences in the cognitive level: neither total loss of objectivity, scepticism, nor irrationality. It actually points to a redefinition of all epistemic notions involved.

Thus, the subjective elements referred to by Kuhn are other factors that are added to the set of conditions and limitations of human cognitive processes; these are other elements that give us a better understanding of the cognitively vulnerable productive dynamics of scientific change.

There are other economic and political elements, which have been repeatedly revealed by political philosophy, especially that elaborated by the Frankfurt-based Critical Theory. ${ }^{10}$ In this case, authors remark that it is important to note how the economic/ political interests affect the processes and results of the research. Specifically, they focus on the interests of the ruling class of capitalist societies. From an epistemological point of view, these interests are partial and are hidden in knowledge processes under the impossible presumption of a subject of universal knowledge, capable of separating itself from such interests. In this way, the results of the research, although presented as universal truths, would actually be as partial as the socio-economic system they would serve and legitimise.

21 This schematic characterisation is enough to show that, in this case, cognitive vulnerability is not linked to epistemic fallibilism, but to an economic and political order that is presented by the authors as undesirable because of the unfair, inegalitarian effects it produces. In this case, the general background vulnerability that we can rebuild does not point to the factum of human psychological faculties (as in the case of Kuhn), but to the factum of human sociability and interdependence, as well as to power relations (understood as domination) that go through all social institutions, including research institutions.

Finally, an analysis like that of Miranda Fricker on "epistemic injustice" reveals other elements that can be considered characteristic of cognitive vulnerability. Following the trail of feminist epistemology, Fricker analyses, on the one hand, what she calls testimonial injustice, caused by the variable credibility and reliability attributed to some subjects of knowledge and not others. On the other hand, she exposes hermeneutic injustice which she understands as that which "occurs at a prior stage, when a gap in collective interpretive resources puts someone at an unfair disadvantage when it comes to making sense of their social experiences" (Fricker 2007: 1). ${ }^{11}$

In this case, the general background vulnerability that we can reconstruct is the same as in the case of Critical Theory, that is, it has to do with the factum of human sociability and interdependence and with the relations of domination that also affect knowledge processes. However, unlike the Frankfurt perspective, Fricker's analysis focuses on the social power that is exercised, either structurally, or by some agents over others, depending on the prejudices that urge the conceptions of social identities in force in each case (for example, the social identity of gender, race, social class, etc.).

24 As has already been said, another difference between the two perspectives is that Critical Theory focuses on explaining the way in which economic (capitalist) interests are hidden in the processes of generating scientific knowledge and therefore favour the perpetuation of these partial interests and the unjust social and political order that accompanies them. This would be socio-political harm, but it also shows epistemic harm that involves operating with falsely neutral (unlinked from values and interests) and ahistorical notions of objectivity and truth. Fricker's perspective, however, deals primarily with the question of how identity-based harm interferes with the fixation 
and recognition of the subject of knowledge. From there, the author points out ethical/ political harm that, as in the previous case, is related to the survival of an unjust social and political order due to the inequality that it entails. However, Fricker wants to highlight the importance of specifically epistemic harm, such as the waste of possible knowledge that entails dispensing with groups whose credibility is devalued (Fricker 2007: 17), or those who are prevented from participating in practices through which social meanings are generated (Fricker 2007: 6).

Epistemic harm would be a crystallisation of what we are calling cognitive vulnerability.

On the other hand, both the Frankfurt and Fricker perspectives highlight a close relationship between knowledge and domination and/or, if I may express it on the broadest conceptual level that I am proposing here, between cognitive vulnerability and a more general vulnerability that goes through social relations.

If we look at this relationship, cognitive vulnerability seems to have degrees according to human groups, since the social and political damage that certain groups already suffer increase their risk of suffering cognitive dysfunctions. That is, the unequal distribution of general vulnerability in social life feeds cognitive vulnerability and vice versa. In this respect, it is not surprising that the two currents of thought develop ethical political reflections of an egalitarian and democratic type, which have an impact to epistemological reflections. This connection between the epistemological and the ethical-political fields takes on a different aspect according to the authors. In any case, along these lines, it is worth remembering that also the pragmatist tradition of thought and, in particular, Rorty's philosophy, contain ethical/political reflections that have an impact to epistemological ones. One of the greatest difficulties in all cases lies in how the passage of vulnerability is recognised as a possibility of specific breakdown, or what specific role epistemic and ethical/political elements play, and how they affect each other. I will return to this topic later in Rorty's work. ${ }^{12}$

Therefore, although neither the Kuhn nor the Frankfurtian analysis, nor that carried out by Fricker, address the problem of cognitive vulnerability, they do however illustrate it. They also allow us to recognise continuity between cognitive and general vulnerability.

Focusing on the case of cognitive vulnerability, it should be added that, when it goes from being a possibility to a reality, it certainly leads to harm, but this does not necessarily cancel out positive possibilities (as a radical sceptic might argue), given that the cognitive dysfunctions are, in principle, as contingent as other human cognitive outcomes. Cognitive dysfunctions can be of different types,,$^{13}$ as can the possibilities of solving them, or the effects they generate. A theory that can be considered imprecise, not very fruitful or even erroneous, for example, does not rule out the possibility of elaborating more precise, more fruitful and more cognitive successful theories. Or, that a certain human group (such as women) has been considered cognitively inferior for centuries, but the possibility of seriously disrupting that opinion has not been ruled out. That is, the actual implementation of cognitive vulnerability is not a reason for epistemological pessimism nor for distrust of human rationality, but a chance for a better understanding of its dynamics. 


\section{The Rorty Case}

After making the previous conceptual clarifications, we can return to Rorty's thinking to show that it is a case of pessimistic fallibilism and cognitive vulnerability.

Fallibilist philosophies usually reflect on fallibilism from an epistemological point of view (about problems of objectivity, justification and truth) and then extend it to all rational activity. Rorty, however, highlights the fallibilism from an ethical point of view (regarding the priority of solidarity over objectivity) and then extends it to all rational activities.

When Rorty speaks of fallibilism he does not mention the idea of error as much as the ideas of objection, a change of vocabulary, or the emergence of some more ingenious hypothesis. Nevertheless, it always relates it to the responsibility of the possible appearance of a new audience before which some of the justified beliefs now lose justification (Rorty 2000a: 4). On the other hand, Rorty oscillates between considering fallibilism either as a human characteristic of our general contingency, and a historicalcultural factor. Thus, in its most epistemological reflections, fallibility is a concrete example of the contingency that affects justification and truth. However, when his reflections focus on issues that go from epistemology to political philosophy (such as the relevance or not of truth to democratic politics), then fallibilism is a cultural factor: "Such fallibilism is not, in fact, a feature of all human beings. It is much more prevalent among inhabitants of wealthy, secure, tolerant, inclusivist societies than elsewhere. Those are the people who are brought up to bethink themselves that they might be mistaken: that there are people out there who might disagree with them, and whose disagreements need to be taken into account" (Rorty 2000a: 4). Perhaps to undo any confusion that might arise from this, it would suffice to differentiate between the existential characteristic (natural for a Darwinian vocabulary like Rorty's) and the recognition of it. ${ }^{14}$

3 Based on this, I will now go on to explain that what distinguishes Rorty's thinking is that the cognitive vulnerability that we can link to his fallibilist position does not focus so much on the permanent possibility of error and the consequent impossibility of achieving unconditional truths, as on the ethical objective of avoiding any relapse into authoritarianism.

However, the path he follows produces an excess of cognitive vulnerability in Rorty's philosophy, which is evident when he addresses the question of how to determine the best out of several theoretical options (or general, cultural belief systems) in conflict. It is in relation to this issue when it becomes clear that his fallibilism is pessimistic, to the point of sometimes appearing irrational, relativistic, antirealistic, or all of them together. Rorty tried to stop this situation (with doubtful success) based on subjecting a particular notion of truth and justification to the ethical background of his thinking.

Rorty's fallibilism surely implies a complex notion of truth and its relationship with justification. In his constant reflections on the subject he sometimes reduces truth to justification, and critically argues that maintaining that the truth leads to justification is the same as believing that, in some way, we can go from the conditioned to the unconditioned. In full conformity with the aforementioned negative logic of fallibilism, Rorty argues that what we can aspire to is a justification before wider audiences, which "leads to less and less danger of rebuttal" (Rorty 2000a: 12). 
36 Along with this, on other occasions he considers it useful to distinguish between truth and justification. Moreover, he does so with the precise intention of highlighting fallibilism, in the sense that distinction makes it possible to accentuate the idea that objections may arise to what at a certain moment is considered true, or to explain the failures we find at a certain moment. ${ }^{15}$ However, he considers that, although the distinction is useful, that does not make it essential, since under no circumstances would it allow us to decide what to believe (Rorty 1998: 19).

Besides this, Rorty also exposes several uses (which are also notions) of truth: ${ }^{16}$

1. disquotational use;

2. use as consensus, as human dialogue;

3. use as a compliment;

4. the commendatory use, the truth as a recommendation;

5. cautionary use.

is the one I want to highlight here since it gives a comprehensive view of fallibility. This use of truth makes it equivalent to justification before a specific and limited audience. To that extent, it acts as a warning of the contingency of its validity, as another auditorium might not endorse it.

One of the risks that follows on immediately after this idea is that of a combination of relativism and anti-realism. In this regard, Rorty constantly repeated that his proposal is outside the classic and sterile dualisms such as the one this objection contains. To make it even clearer, he decided to describe his position as ethnocentric. Such denomination, among other aspects, referred to the fact that all truth and justification are established by the members of a specific audience through their linguistic interactions. To understand this better, it is important to add to this that Rorty explained this social interactivity through Davidson's triangulation theory, or rather, a certain interpretation of it.

40 Far from the risks of dualistic approaches, Rorty finds in the triangle proposed by Davidson the vaccine against all metaphysical dogmatism and scepticism. The triangle is composed of three vertices (speaker, interpreter and world) that cannot be conceived atomically. It is also through this interaction, which includes the "world" vertex, that the reference to linguistic expressions can be accounted for outside representationalism. This reference is not the result of a mere causal relationship (although it does include it), but arises from maximising coherence and truth in interactions with others (Rorty 1991: 134 et sq.). Along with this, the interaction is guided by what Davidson, inspired by Quine, called the principle of interpretive charity, which assumes that others are rational in what they do and say.

41 Rorty partially accepted this proposal. He accepted it because he adopted the Davidsonian notion of reference when he incorporated into his thinking the idea that Davidson expressed in "On the Very Idea of a Conceptual Scheme." In fact, he quoted this affirmation by Davidson verbatim: "In giving up the dualism of scheme and world, we do not give up the world, but re-establish unmediated touch with the familiar objects whose antics make our sentences and opinions true or false" (Rorty 1979: 310). Thus, the theoretical goals of Rortyan linguistic pragmatism have always been clear: there was no room for linguistic idealism.

But that acceptance was partial, since he showed his disagreement with the Davidsonian defence of a certain notion of truth as correspondence (Rorty 1991: 138). 
Against this, he always underlined the aforementioned cautionary use of the truth (what may be justified for one audience may not be for another), thereby accentuating the fallibility of justification and truth and, to this extent, of what we are calling cognitive vulnerability.

What Rorty did not seem to see is that the semantic dimension of the issue is not incompatible with cautionary use. In our interactions, from the most ordinary to the most sophisticated, the use of truth as correspondence is continually present. ${ }^{17}$ What we are talking about in each case is, thus, understandable. Furthermore, this is perfectly compatible with maintaining a certain epistemological precaution regarding its justification. In other words, caution affects justification, not the use of truth as correspondence that is supported by reference. To consider, as Rorty does, that any use of truth as correspondence is representational and foundationalist in the classical way is to fall into one of those dualistic approaches that he criticized so much; or rather, engaging in the aforementioned Cartesian anxiety: or the use of truth as correspondence understood in the classical way, or no use of truth as correspondence at all.

It must also be added that, together with this recognition of the presence of the "world" vertex in the reference setting and its limited scope in terms of the notion of truth, a marked inoperativeness of said vertex is found in Rorty when he repeatedly argues against any idea of evidence, that is, against any idea of experience with justification functions. This problem is particularly palpable when addressing the problem of choosing the best of several options in conflict.

Rorty understands the notion of evidence exclusively as a "given" objective scope and with foundationalist epistemic functions. He rejects the role of experience as "felt or had" in cognitive justification (Rorty 1979: 184). He considers this an invention, an appeal to gods, a metaphysical comfort, a recourse to magical mediators. ${ }^{18}$ Even in his criticisms of essentialism that involves any representationalism in his opinion, he sustains the need to forget about that "doubtful interface" that is perceptual experience (Rorty 1991: 91). The alternative of proposing an anti-foundationalist notion of evidence is the same for Rorty as when 'the question, 'Is there any evidence for $p$ ?' gets replaced by the question, 'Is there any way of getting a consensus on what would count in favour of $p$ ?"” (Rorty 1999: 155).

Certainly, Rorty accepts that who, like himself, adopts the anti-essentialist position is not an idealist, but a coherentist, since he admits that he "is no more free from pressure from outside" and "there are objects which are causally independent of human beliefs and desires" (Rorty 1991: 101). However, in the processes of justification, he believes that the anti-essentialist coherentist like himself is only obliged to try to fit some new belief into his own already-existing network of beliefs. So, if you are a coherentist anti-essentialist, "then we shall say that all inquiry is interpretation, that all thought consists in recontextualisation, that we have never done anything else and never will" (Rorty 1991: 102). This is explicitly added to by total dissociation between the reference - which can be explained through causal, unintentional and nonrepresentational links ${ }^{19}$ (Rorty 1991: 148) - and the verificationist justification that resorts to evidence. Otherwise, one falls into the old metaphysical desire for correspondence between words and reality itself.

47 The critical dialogue between Rorty and Bjørn Ramberg is illustrative on this issue. The latter, accepting like Rorty the basic ideas of Davidson's triangulation theory, pointed 
out the need to admit the differential truth/error pair not only on the semantic level, but also as an indispensable element of the intersubjective linguistic practices of justification. He also pointed out that these practices require the use of descriptive vocabularies that show "something as a kind of thing. But this is just to say that any linguistic utterance, as opposed to a mere noise, will have appropriateness-conditions" (Ramberg 2000: 363). The importance of this lies in the fact that it enables the reciprocal, normative evaluation of alternative descriptions: "Vocabularies can be evaluated, in so far as different vocabularies may serve different purposes and interests. But human purpose and interest provide both the framework for individuations of vocabularies, and the ultimate terms of any evaluation" (Ramberg 2000: 365).

Rorty's response is positive and clearly affirms that "none of the three corners of his process of triangulation can be what they are in independence of the other two." However, this affirmation is preceded by another one that once again identifies correspondence with representation in the fundamentalist sense: "If you think that that glib and ethnocentric answer is not good enough, that is because you are still in the grip of the scheme-content distinction. You think you can escape the inescapable, cut off one corner of Davidson's triangle, and just ask about a relation called 'correspondence' or 'representation' between your beliefs and the world" (Rorty 2000c: 374).

The key to a better understanding of this answer lies in that same volume, but in the response to Brandom. That is where he makes clear that the problem is not so much the truth/error pair, or the connection between description, correspondence and evaluation, as the dogmatic, authoritarian drift that arises from it: "My fear is that countenancing these dangerous idioms will be taken as a concession by the bad guys: the people who still use perceptual experience as a model for 'hard facts' and who think that photon-talk is somehow harder than talk about comparative aesthetic worth. These bad guys are the people I think of as 'authoritarians.' These guys do not agree with Brandom and myself that increased freedom and richness of the Conversation is the aim of inquiry, but instead think that there is the further aim of getting Reality right (as opposed to getting, for instance, snow, photons, baseball, Cezanne and the best use of the term 'fact' right)" (Rorty 2000b: 187).

To sum up, Rorty believes that the only alternative to his own position is the one that handles an idea of evidence, of facts of the matter, or of experiential inputs, which would necessarily imply a representationalist, antipluralist, essentialist, fundamentalist and, in short, authoritarian dogmatic perspective.

51 With regard to this issue, the first thing that can be said is that Rorty is once again the prey of Cartesian anxiety, since he reasons in terms of extreme dualism: either one opts for his coherentist anti-essentialism that assimilates justification to recontextualization, or a notion of evidence and perceptual experience is used that is necessarily essentialist and assimilates justification to the idea of absolute metaphysical foundation, whose reflection in life is authoritarianism.

Once again we can see that his goal is clear: to avoid the authoritarianism that springs from foundationalist representationalism. We can see also that he is creating a theoretical scenario in the service of that goal: a conversational, open, dynamic picture of rationality. But that philosophical scenario is missing a concept that captures everyday usage - "homely and shopworn" (Rorty 1979: 307) - of experience or 
evidence. There is no reason to suppose, as Rorty does, that the philosophical use of those terms in relation to justification necessarily entails an authoritarian notion of experience or evidence. Even from a pragmatist point of view "for example, it could be argued that a pragmatism oriented to the 'linguistic turn' can only profit from a reconstruction of the notion of experience; instead of rejecting it, 'linguistic pragmatism' should include the different shades of this notion that Peirce, James and Dewey developed in their philosophies, but avoiding as well to suggest it - as they sometimes seemed to do - as a foundationalist criterion" (Calcaterra 2019: 38).

Additionally, if we think about controversial situations, the result of this Rortyan conceptual lacuna would be that to forge what is best would be reduced to a conversational process which would be about persuading the opponent, that is, convincing him through arguments and reasons governed by solidarity, but without decisive empirical charge.

Therefore, epistemic processes of justification for choosing one of several options would become pure linguistic exchange between speakers and interpreters of one or several ethnos, without a relevant role for the (Davidsonian) angle of the world.

In this way, Rorty takes cognitive vulnerability to the extreme, since his fallibilism becomes greatly pessimistic because it lacks of any notion of experience to use as evidence to determine what is best to believe (always contingently) in relation to the apex of the world. However, as indicated above, he always argued that his ethnocentrism is not a relativism in which anything goes; it is possible to emerge from disputes and establish the best among several options. How? Through a combination of solidarity and imagination: imagining which option would be the best from the point of view of "a better version of ourselves." 20

The "ourselves" refers to Westerners, liberals and moderates. As for the specific meaning of the adjective "better" (which is the one that contains the burden of solidarity), Rorty includes it several times in his work ${ }^{21}$ and at the base of its meaning is the pounding of an idea that William James presented in his work entitled The Will to Believe (James 1912: 210), more specifically, the idea that it is necessary to be open to listen to "the cries of the wounded" to increase our knowledge and sense of justice. This reflection is integrated by Rorty in his characterisation of the figure of the ironist. He therefore states that "she thinks that what unites her with the rest of the species is not a common language but just susceptibility to pain and in particular to that special sort of pain which the brutes do not share with the humans - humiliation" (Rorty 1989: 92 et sq.).

Such human resemblance in pain and humiliation, combined with his notion of contingency of the self, of every human community and, ultimately, of all that is human, can easily be reformulated as our similarity with regard to vulnerability understood as an existential condition. In Rorty's work there is no careful analysis of the concept of vulnerability, ${ }^{22}$ however, in his way of presenting the notions of humiliation and solidarity we can see both a double sense of vulnerability in general and its relationship with what we are now calling cognitive vulnerability. Indeed, it is possible to reconstruct a notion of existential vulnerability with a negative sense, for example, when he mentions human fear of pain and death, or the fear of not surviving in some way after death that (in his opinion) exists in supporters of objectivity versus solidarity (Rorty 1991: 31). However, his work also shows a glimpse of a positive sense of vulnerability as a deep root of human contingency. ${ }^{23}$ The transformation of this 
negative charge of vulnerability into a positive one requires the acceptance of contingency, since it implies (in Rorty's eyes) a dynamic opening to others, their expressions and their belief systems (this is the field of cognitive vulnerability). In fact, it is an opening that is always driven by the ethical ideal of solidarity.

Furthermore, in this same conceptual framework, Rorty relies on linking the private and public sphere of human lives through their respective ethical requirements. $\mathrm{He}$ therefore links, on the one hand, the value of self-creation of the individual in its uniqueness and, on the other, the value of social solidarity, which he considers inherent to any democratic political project that deserves that name, and to any activity that wishes to contribute to that project (starting with science and philosophy). Even so, Rorty bases the norms of all rational interaction on a democratic social ethics developed on the existential background of vulnerability.

In short, to alleviate the pessimistic consequences of an extreme development of cognitive vulnerability, which stem from his rejection of any notion of evidence, Rorty resorts to an optimistic idea of an improved future "us," whose meaning depends ultimately on understanding vulnerability as an existential condition common to humans.

In this regard, I will first merely point out that Rorty does not clarify how his notion of an "improved us" avoids being another case of metaphysical comfort, or rather, why his utopia is less metaphysical than, for example, the idea of truth as convergence. Certainly his utopian "better versions of ourselves" does not rely on any necessary $a$ priori need, and is a hope that goes from the present to the future, but that does not prevent its character of counterfactual utopia, of invention.

Secondly, this part of Rortyan thought once again clearly shows the antidogmatic and antiauthoritarian goals that guide the author. It is also apparent that in the structure of his theory the hopeful optimism associated with the concept pair vulnerabilitysolidarity has the task of balancing the excessive pessimism entailed by his notion of fallibilism without evidence. But it is not successful, as we can see in the effects derived from the theory.

No doubt those effects were not sought or hoped for by Rorty himself, since throughout his voluminous work he repeated in a thousand different ways that he did not intend to alter the ordinary way of using "knowing," "objective," "fact," and "reason," but only the comments that inherited philosophy made about that mode of speech (Rorty 1998: 44). That is, he distinguished between the ordinary use of those terms and the abusive use made by the philosophical traditions that enthroned privileged descriptions. As we have stated in this text, the reason (the goal) that moved him was to avoid at all costs the authoritarianism that inherited tradition entails.

However, the Cartesian anxiety present in his philosophy leads to unsought consequences that do alter the ordinary way of speaking. Or to say it more clearly, his philosophical project becomes disconnected from ordinary speech. Despite his laudable goals, the structure of Rortyan thought has a conceptual lacuna that makes it impossible to reflect philosophically on an epistemic activity (the activity of adducing or requesting evidence) that is a normal part of conversational exchanges such as controversies. On the other hand, the Rortyan proposal has as an unexpected consequence, which is the aggravating factor of blocking the path to deal with such serious phenomena as the spread of post-truth, of "alternative facts." 

descriptive languages and truth as correspondence, and distinguish between appearance and reality. Furthermore, in argumentative exchanges we forge empirical evidence to support our reasons. We sometimes do all this by adding some metaphysical counterfactual, and on other occasions we don't. If only for this reason, philosophy cannot ignore the (semantic) question of reference and its link with truth as correspondence and the (epistemic) question of evidence, as if any possible notion of them were immediately false idols. In the ordinary way of speaking, both are closely related and, therefore, must be rethought taking into account human cognitive vulnerability. The semantic dimension of what we say acquires (or does not acquire) epistemic evidential value in argumentative exchanges themselves, which are undoubtedly interlinked with interpretation. But, an argumentative exchange without a semantic dimension is mere fiction and, in the worst case, lies and manipulation (as when talking about alternative facts). To this extent, it is ineffective in combating authoritarianism.

The concept pair vulnerability/solidarity is fundamental to all conversational activity, since (as we have said) it entails dynamic openness towards others, to what they say and to their systems of belief. As such, the concept pair affects our judgements and reasoning by the ethical implications that it entails. ${ }^{24}$ However, ethical and political reasons do not replace and do not deactivate the value of epistemic reasons although they do combine and reinforce each other. That is, ethical and political reasons do not change reality, although they change our concepts, our way of seeing it and establishing what counts as evidence. For example, an understanding of gender-based violence includes ethically despicable acts (such as that a husband murders his wife when she wants a divorce) that at other times have been considered ethically acceptable (by virtue of a code of honour). Here we have a single event (someone takes the life of another) seen as despicable in one case and honourable in another. ${ }^{25}$ Whether it is in the end evidence of murder or evidence of honour restored is something that can be explained by, for example, that branch of philosophy that is the argumentation theory. In effect, whether we are disposed to see it in one way or another in a controversial situation passes through a conversational exchange in which we use every kind of argument, that is, ethical and emotional arguments too. ${ }^{26}$ But the ethical force of an argument cannot replace its empirical force.

Whether following this theoretical-argumentative path (with Wittgensteinian background), whether through linguistic pragmatism (mentioned above), we can see that there is room in philosophy for the development of a concept of evidence outside of the category of necessity. We can see that evidence can be understood from within philosophy as something hammered out in language through conversational exchanges in which solidarity is also central.

62 The ethical interest that guides Rorty's pragmatism is embodied with the brilliance that characterized him in a well-known statement that became his motto: "If we take care of freedom, truth can take care of itself" (Rorty 1989: 176). However, there are several vocabularies about freedom, and we have (contingent) evidence that those that trivialise the truth involve authoritarianism. That is why it is necessary to take care of both at the same time; they nicely complement each other. 


\section{BIBLIOGRAPHY}

BECK Aaron T., RUSH A. John, SHAW Brian F. \& Gary EMERY (1979), Cognitive Therapy of Depression, New York, Guilford Press.

BERNSTEIN Richard J., (1983), Beyond Objectivism and Relativism, Philadelphia, University of Pennsylvania Press.

BERNSTEIN Richard J., (1986), Philosophical Profiles: Essays in a Pragmatic Mode, Cambridge, Polity

Press.

BERNSTEIN Richard J., (2010), The Pragmatic Turn, Cambridge, Polity Press.

CALCATERRA Rosa Maria, (2019), Contingency and Normativity. The Challenges of Richard Rorty, Leiden/ Boston, Brill/Rodopi.

FRICKER Miranda, (2007), Epistemic Injustice. Power and the Ethics of Knowing, Oxford, Oxford University Press.

GAMERo Isabel, (2019), "Cantar con voz propia (y que se escuche). Puentes entre perfeccionismo moral y justicia epistémica," Análisis. Revista de investigación filosófica, 6 (2), 129-51.

GONZÁLEZ CASTÁN Óscar L., (2013), “The Nest Structure of Our Belief System and Its Consequences," Wittgenstein Studien, 4, 65-94.

JAMES William, (1912), The Will to Believe and Other Essays in Popular Philosophy, London et al., Longmans, Green, and Co. [gutenberg.org/files/26659/26659-h/26659-h.htm\#ch06fn1] Acceso 5 de enero de 2020 .

KUHN Thomas S., (1977), “Objectivity, Value Judgment, and Theory Choice,” The Essential Tension, ch. XIII, Chicago, The University of Chicago Press.

PERONA Ángeles J., (2016), “Pluralism and Soft Rationality in the Philosophy of Ortega and Wittgenstein,” in J. M. \& A. Wagner (Hgs.), Glauben und Wissen, Berlin/Boston, De Gruyter (BSKR Band 9), 75-87.

PERONA Ángeles J., (2018), “Soft Rationality and Reticulated Universality. Reflecting on the Debate between R. Rorty and H. Putnam," in M. Hetmanski (ed.), Rationality and Decision Making. From Normative Rules to Heuristic, Poznán Studies in the Philosophy of the Sciences and the Humanities, vol. 111, Leiden/Boston, Brill/Rodopi, 93-118.

PUTNAM Hilary, (1981), Reason, Truth and History, Cambridge MA and London, Cambridge University Press.

PUTNAm Hilary, (1999), The Threefold Cord. Mind, Body, and World, New York, Columbia University Press.

RAMBERG Bjørn, (2000), "Post-Ontological Philosophy of Mind: Rorty versus Davidson," in R. B. Brandom (ed.), Rorty and His Critics, Malden MA and Oxford, Blackwell, 351-70.

RORTY Richard, (1979), Philosophy and the Mirror of Nature, Princeton, Princeton University Press. RORTY Richard, (1989), Contingency, Irony and Solidarity, Cambridge, Cambridge University Press. RORTY Richard, (1991), Objectivity, Relativism and Truth. Philosophical Papers 1, Cambridge, Cambridge University Press. 
RORTY Richard, (1998), Truth and Progress. Philosophical Papers 3, Cambridge, Cambridge University Press.

RORTY Richard, (1999), Philosophy and Social Hope, London et al., Penguin Books.

RORTY Richard, (2000a), "Universality and Truth," in R. B. Brandom (ed.), Rorty and his Critics, Malden MA and Oxford, Blackwell, 1-30.

RORTY Richard, (2000b), "Response to Robert Brandom," in R. B. Brandom (ed.), Rorty and His Critics, Malden MA and Oxford, Blackwell, 183-90.

RORTY Richard, (2000c), "Response to Bjørn Ramberg," in R. B. Brandom (ed.), Rorty and His Critics, Malden MA and Oxford, Blackwell, 370-77.

VILANOVA Javier, (2015), Al menos sé que sé algo. Estrategias argumentativas para fundamentar el conocimiento, Madrid, Escolar y Mayo.

VILANOVA Javier, (2019), “Escepticismo, tragedia y vulnerabilidad cognitiva. Una lección de Cavell," Análisis. Revista de investigación filosófica, 6 (2), 167-85.

WALton Douglas N., (1992), The Place of Emotion in Argument, Pennsylvania, Pennsylvania State University Press.

\section{NOTES}

1. Rorty derives important epistemological ideas from this, one being that distinction between knowledge is not essential. The distinction between sociology and physics, for example, is sociological, not methodological. They simply constitute different vocabularies (Rorty 1991: 102-3). So, all knowledge becomes understood as voices in conversation of humankind guided by solidarity (and not by objectivity).

2. Error and doubt may arise both from faculties, judgments and all the technical support equipment involved in rational activities.

3. I use the expression "soft rationality" to refer to an image of rationality that is dynamic in epistemological terms, since it conceives knowledge and action as qualitatively plastic, open and flexible social activities. It produces plural and contingent results, since they are always empirically underdetermined. However, at the same time, it is an image that contains limits for that plurality, since it is minimally although not a priori normative. I developed this idea in Perona (2016).

4. Javier Vilanova justifiably defends the need for epistemology to go from discussing infallibility to discussing successability: "We must stop traumatising ourselves due to the difficulty, complexity and scarcity of knowledge and start examining the factors that lead us, even in spite of so many impediments, to reach that desired situation that we believe; we have reasonable justifications and, above all (even if it is some sort of luck), what we believe corresponds to the facts" (Vilanova 2015: 166).

5. Popper ended up contradicting this. On the one hand, he always maintained the idea that truth is an unattainable regulatory ideal, in the sense that we cannot know that any of our theories (or part of them) are true, even if they are; only their contingent corroboration or verisimilarity can be found. However, the contradiction came from his attempts to establish the degree of verisimilarity of a theory, which transformed his notion of verisimilarity into a sort of percentual approach to the truth.

6. I dealt with that debate in Perona (2018).

7. For a more current realistic proposal see the work of Tim Williamson, for example. 
8. This concept was introduced by Óscar González Castán to explain situations that go beyond mere fallibilism: "However, children's discovery of their absolute cognitive vulnerability is not the same thing as the discovery of their fallibilism. Rather it is the discovery that, previous to any use of limited and fallible cognitive faculties and previous to any scientific hypothesis or to any sophisticated idea, their lives have been permeated by beliefs and behaviours of an absolute certainty but, nevertheless, of an absolutely empty certainty. [...] These second order epistemic beliefs might give us a permanent sense of vulnerability and distrust. They give us a sense of deepness and despair because we can no longer have an absolutely confident cognitive relationship with any of our beliefs, with the world, and, in fact, with ourselves. Sceptical philosophy has biographical roots" (González Castán 2013: 29-30). See below for further information on this concept: Vilanova (2019) and Gamero (2019).

9. Cf. Beck et al. (1979). However, there are other psychological currents that, aside from pathological cases that require psychiatric treatment, offer a less negative image of cognitive vulnerability. Specifically, in therapies that use negotiation it is considered that there is nothing pathological in itself or anything curative in itself, but rather an imbalance that causes problems. Therapy consists of detecting the problem and negotiating the reestablishment of equilibrium with patients. I would like to thank José $\mathrm{M}^{\mathrm{a}}$ Ariso for this clarification.

10. On this issue, it is worth mentioning a huge bibliography that goes from the opening text of Max Horkheimer Traditionelle und kritische Theorie to the emblematic book by Jürgen Habermas Erkenntnis und Interesse.

11. On this same page the author illustrates her notions with these examples: "An example of the first might be that the police do not believe you because you are black; an example of the second might be that you suffer sexual harassment in a culture that still lacks that critical concept."

12. I am not going to analyse here the way in which this relationship is specified in Fricker's work or in the work of Frankfurtians like Habermas, because it goes well beyond the boundaries of this work.

13. In relation to the general notion of vulnerability, it would be interesting to explore whether harm can be discussed on its own, or that the fact that what constitutes harm depends on each social context. However, this goes well beyond the boundaries of this text.

14. Rorty does not make an analysis of this question, but he does choose the theoretical framework that he considers most useful to talk about human contingency at all levels, that is, Darwinism. But it is important to insist that Darwinism for Rorty is a vocabulary. To that extent it is not a kind of first philosophy we can use to discover the essence of human nature; but it is rather a way of speaking that portrays an image of human beings. The approach is deeply antiessentialist, but does not exclude the possibility of talking about existential conditions, since the difference between the latter and essences is valid.

15. This is the case, for example, when he states the following: "In non-philosophical contexts, the point of contrasting truth and justification is simply to remind oneself that there may be objections (arising from newly discovered data, or more ingenious explanatory hypotheses, or a shift in the vocabulary used for describing the objects under discussion) which have not yet occurred to anyone" (Rorty 2000a: 4).

16. Rorty exposes these uses repeatedly throughout all his works, but perhaps the best places to get an overview are "Pragmatism, Davidson and Truth" (Rorty 1991: 126-50) and "Is Truth a Goal of Inquiry? Donald Davidson versus Crispin Wright?" (Rorty 1998: 19-42).

17. A use that is not always supported by the representation understood from the visual metaphor of the mirror. It is often an instrumental representation like that of a blind person with his cane.

18. Cf., for example, the criticism of the notions that Hilary Putnam handles of "experiential inputs" or, subsequently, "a matter of fact" (Rorty 1998: 43-62). There Rorty did not capture the relevance of the fact that in Reason, Truth and History Putnam made it clear that he did not 
understand inputs beyond conceptual-linguistic structures: “[...] it does deny that there are any inputs which are not themselves to some extent shaped by our concepts, by the vocabulary we use to report and describe them, or any inputs which admit of only one description, independent of all conceptual choices" (Putnam 1981: 54).

19. Rorty believes that the aforementioned Darwinian vocabulary is especially useful for explaining the type of causal (non-representational) relationships that human animals have with the surrounding world. Cf. Rorty (1998: 47 et sq.).

20. According to Rorty, this possibility does not imply that emergence is always satisfactory from the point of view of the moral parameters of the tolerant, liberal, etc., us. An example of this is in the long debate he had with Putnam and, in particular, in his Darwinist response to the question that Putnam asks him about what he would call upon to present as a normatively unacceptable a hypothetical triumph of the Nazi form of life. In his opinion, in those circumstances "I cannot, indeed, appeal to such a 'fact of the matter,' any more than a species of animal that is in danger of losing its ecological niche to another species, and thus faces extinction, can find a 'fact of the matter' to settle the question of which species has the right to the niche in question" (Rorty 1998: 51). This response is consistent with his idea (already mentioned before) of fallibilism as a historical-cultural factor that not all human groups include; the belief system of the world image of the Nazi does not contemplate the possibility of the fallibility of its own beliefs. This certainly prevents the exchange of reasons and arguments to resolve the confrontation between life forms and their corresponding belief system.

21. For example, in Rorty (1998: 51 et sq.).

22. His work contains some uses of the concept, for example, in "Religion as Conversationstopper," he says that we have vulnerable bodies (Rorty 1999: 169).

23. See Calcaterra (2019) to capture the centrality in Rorty's thinking of his complex notion of contingency.

24. In all these arguments, the key idea is that we cannot resort to any authority besides ourselves and other human beings. This is what Richard Bernstein refers to when he talks about Rorty's "Deep Humanism" (Bernstein 2010: 211).

I am not going to discuss here the question of why Rorty, who is always so critical of inherited tradition, sees it necessary to reintroduce some version of humanism and universalism. I will only mention that the reasons are political and ethical (strengthen cosmopolitanism and democratic politics as ways to reduce pain and humiliation) and that, for him, universality would be something that can be created gradually, but not something previously existing. Cf. Rorty (2000a: 17).

25. I understand "to see as" in the sense used by the later Wittgenstein. Note that it implies a pluralism of human perspectives and never a "God's eye" view perspective.

26. Cf. Walton (1992). This book is particularly interesting in relation to the question that we are addressing, because among other things it categorizes evidence by different notions (hard evidence, soft evidence, source-based evidence, etc.).

\section{ABSTRACTS}

In this text, the relationship between fallibilism and cognitive vulnerability is examined using Richard Rorty's thinking as an example. First, some of Rorty's central ideas are collected and commented on, especially the substitution of objectivity for solidarity, since it affects relevant 
issues of epistemology and of reflection on rationality. Next, the notions of fallibilism and cognitive vulnerability are examined, which will be connected to an existential dimension of vulnerability. Examples of all those things are also given from Rorty's thinking and it is highlighted that the author operates with both a negative and a positive sense of existential vulnerability. It is then stated that Rorty's proposal implies pessimistic fallibilism and an excess of cognitive vulnerability. First, it is argued that the cause of this lies in the fact that his approach is imprisoned in what Richard Bernstein called Cartesian anxiety and secondly, this generates unwanted consequences for the Rortyan goals themselves to raise his ethnocentric proposal as a non-relativistic alternative to realism and authoritarianism. In this respect, it is maintained that the priority that Rorty attributes to solidarity is accompanied by the rejection of any notion of evidence. This produces a conceptual lacuna in the structure of his thought that makes it impossible to reflect philosophically on an epistemic activity (the activity of adducing or requesting evidence) that is a normal part of day-to-day conversational exchanges as important as controversies to determine the best option in each case. In response, we will argue that one can better work towards the achievement of Rortyan goals if we bear in mind that reasons based on solidarity do not replace and do not deactivate the value of epistemic reasons, although they do combine and reinforce each other.

\section{AUTHOR}

\section{ÁNGELES J. PERONA}

Universidad Complutense de Madrid

anperona[at]filos.ucm.es 